\title{
Clinical Features of Myasthenia Gravis Patients': The Assessment of 138 Patients
}

\section{Myastenia Gravis Hastalarının Klinik Özellikleri: 138 Hastanın Değerlendirilmesi}

\author{
Mehlika Panpallı Ateş \\ Health Sciences University, Dışkapı Yıldııım Beyazıt Training and Research Hospital, Clinic of Neurology, Ankara, Turkey
}

\begin{abstract}
Aim: The aim of this study was to evaluate the demographic characteristics, clinical presentation, antibody, and electrophysiological characteristics of patients with the diagnosis of Myasthenia Gravis (MG).
\end{abstract}

Material and Method: The demographic characteristics, clinical presentation, antibody, electrophysiological and radiological (thoracic tomography) characteristics of the patients who were followed in the Neuromuscular and Muscular Diseases Polyclinic of the hospital between 2014-2019 were analyzed.

Results: The mean age of the patients was $53.8 \pm 16.67$ years. The mean disease duration was $4.8 \pm 5.05$ years. Ptosis was the most common complaint in $79 \%(n=109)$ of our patients. The number of patients followed as pure ocular MG was $61.6 \%(n=85)$. There were 26 patients who presented with ptosis or diplopia at the first presentation and follow-up generalized MG with bulbar findings and weakness. Acetylcholine receptor antibody (AntiAChRAb) positivity was found in $78.3 \%(n=108)$ of the patients and thymus pathology was detected in thorax tomography in $37.7 \%(n=52)$.

Conclusions: The initial complaint provides little insight into the course of the disease. The important factor is clinical follow-up. Although MG treatment is known, the pathophysiology of MG remains to be elucidated, and other autoimmune conditions cause changes in treatment choice. Therefore, an important point in MG management; is the choice of individualized therapy.

Keywords: Acetylcholine receptor antibody, Myasthenia Gravis, pyridostigmine, thymoma
Öz

Amaç: Bu çalışmanın amacı, Myastenia Gravis (MG) tanısı ile izlenen hastaların demografik özellikleri, ilk başvuru şikayeti ile klinik seyir antikor ve elektrofizyolojik özelliklerini değerlendirmektir.

Gereç ve Yöntem: 2014-2019 yılları arasında, hastanemiz Nöromusküler ve Kas Hastalıkları Polikliniği'nde takip edilen yüz otuz sekiz MG hastasının demografik özellikleri, ilk başvuru şikayeti ile klinik seyri, antikor, elektrofizyolojik ve radyolojik (toraks tomografi) özellikleri incelendi.

Bulgular: Hastaların yaş ortalaması 53,8 $\pm 16,67$ idi. Ortalama hastalık süresi 4,8 $\pm 5,05$ yll idi. Hastalarımızın en sık, ilk başvuru şikayeti \%79 ( $n=109$ )'unda ptozis idi. Saf oküler MG olarak takip edilen hasta sayısı \%61,6 ( $n=85$ ) kişiydi. Illk başvurusunda ptozis veya diplopi şikayetiyle gelip, daha sonrasında bulber bulgular ve güçsüzlük eklenerek jeneralize MG düşünülen 26 hasta bulunuyordu. Hastaların \%78,3 ( $n=108$ )'ünde asetil kolin reseptör antikoru (AntiAChRAb) pozitifliği ve $\% 37,7(n=52)$ 'sinde toraks tomografide timüs patolojisi bulundu.

Sonuç: Illk başvuru şikayeti hastalığın seyri hakkında çok az fikir vermektedir. Asıl önemli olan, klinik yakın takiptir. Her ne kadar MG tedavisi bilinse de MG'in patofizyolojisi halen tam olarak aydınlatılamamıştır ve diğer otoimmun durumlar tedavi seçiminde değişikliğe neden olmaktadır. Bu nedenle de MG yönetiminde önemli bir nokta; bireyselleştirilmiş tedavi seçimidir.

Anahtar Kelimeler: Asetilkolin reseptör antikoru, Myastenia Gravis, pridostigmin, timoma

Corresponding (illetişim): Mehlika Panpallı Ateş, Ziraat Mah. Şehit Ömer Halisdemir Caddesi, No:20, Dışkapı Yıldırım Beyazıt Eğitim ve Araştırma Hastanesi, Nöroloji Kliniği, F blok 3. kat, Nöroloji Kliniği, 06110 Dışkapı/Ankara, Türkiye

E-mail (E-posta): muefhulkika@gmail.com

Received (Geliş Tarihi): 01.06.2021 Accepted (Kabul Tarihi): 29.06.2021 


\section{INTRODUCTION}

MG symptoms occur with an autoimmune attack or damage to the neuromuscular junction (NMJ). Its clinical feature is a symptomatic weakness that is predominant in some muscle groups and typically fluctuates with increased effort and a decrease in response to rest. The diagnosis of MG is primarily based on the clinical history and examination findings that show this apparent pattern of weakness and can be confirmed using a series of diagnostic tests. However, not all patients have this classic clinical feature, and variable or atypical presentations may be seen. ${ }^{[1]}$

Although MG is a relatively rare disease, its prevalence rates have approached 20 per 100,000 in the US population and have increased over time with recent estimates. ${ }^{[2]}$ Recent studies show that MG is becoming increasingly widespread, particularly in the elderly. ${ }^{[1,3]}$

The incidence of MG is between 9 and 30 in 1 million, while the prevalence is between 100 and 140 in 1 million. However, last reports have shown that its prevalence is more than 200 per 1 million. ${ }^{[1,4,5]}$ While in the first five decades of women's lives diagnosed have MG is higher men are more likely to be diagnosed MG after the age of 50..$^{[1,6]}$ Patients with ocular MG and prepubertal juvenile MG are more common, particularly in people of Asian descent and men with late-onset MG. Anti-muscle-specific tyrosine kinase (Anti-MuSK) positive MG is more common in young women and possibly in the nonwhite population. ${ }^{[1,6]}$

MG physiopathology is still not fully understood, but it is known that neuromuscular transmission is inhibited by the formation of antibodies against proteins at the neuromuscular junction. Antibodies opposite to AChR, the most common antigenic target in MG, are present in $85 \%$ of patients with generalized MG and $50 \%$ of patients with ocular MG and prevent neuromuscular transmission..$^{[1,7,8]}$ In more than half of antiAChRAb negative generalized MG patients, antibodies target other proteins in the NMJ. The first described and still most common antibodies against MuSK. ${ }^{[1,9]}$ More recently, antibodies against lipoprotein receptor-associated protein 4 (LRP4), cortactin, and agrin have been described, but a group of patients without antibodies are still defined as seronegative myasthenia gravis (SNMG). ${ }^{10]}$

Most antiAChRAb positive MG patients have pathological thymic involvement, either thymic hyperplasia or thymoma. Thymic hyperplasia occurs in $50-80 \%$ of postpubertal adolescents and in cases of early-onset AntiAChRAb positive MG. Thymic hyperplasia is rare in Anti-MuSK positive MG. It is less common in seronegative and late-onset MG, where the thymus is usually found in the normal, atrophic, or thymoma form. ${ }^{[1,11,12]}$ An important source of anti-AChR antibodies is the hyperplastic thymus. Thymoma is found in $10-20 \%$ of patients with MG, and MG is seen in 30-50\% of thymoma cases. ${ }^{[1,11,13]}$ The prevalence of other autoimmune diseases, particularly thyroid, has increased in MG patients and their family members. While it occurs between $13-30 \%$ in patients with MG, it is between $5-8 \%$ in the general population. A genetic effect is mentioned in autoimmune diseases, MG is the least common disease among them. ${ }^{[1,14,15]}$ Widely used in the classification of MG; The American Myasthenia Gravis Foundation Clinical Classification is a useful scale for both research and general clinical purposes (Table 1). ${ }^{[16]}$

\begin{tabular}{|c|c|}
\hline Class I & $\begin{array}{l}\text { MG is characterized by the following: } \\
\text { i. any ocular muscle weakness. } \\
\text { ii. may have weakness of eye closure. } \\
\text { iii. all other muscle strengths are normal }\end{array}$ \\
\hline Class II & $\begin{array}{l}\text { MG is characterized by the following: } \\
\text { i. mild weakness affecting muscles other than ocular muscles, } \\
\text { ii. may also have ocular muscle weakness of any severity }\end{array}$ \\
\hline Class Ila & $\begin{array}{l}\text { MG is characterized by the following: } \\
\text { i. predominantly affecting limb, axial muscles, or both } \\
\text { ii. may also have lesser involvement of oropharyngeal } \\
\text { muscles. }\end{array}$ \\
\hline Class Ilb & $\begin{array}{l}\text { MG is characterized by the following: } \\
\text { i. predominantly affecting oropharyngeal, respiratory } \\
\text { muscles, or both, } \\
\text { ii. may also have lesser or equal involvement of limb, axial } \\
\text { muscles, or both. }\end{array}$ \\
\hline Class III & $\begin{array}{l}\text { MG is characterized by the following: } \\
\text { i. moderate weakness affecting muscles other than ocular } \\
\text { muscles, } \\
\text { ii. may also have ocular muscle weakness of any severity. }\end{array}$ \\
\hline Class IIla & $\begin{array}{l}\text { MG is characterized by the following: } \\
\text { i. predominantly affecting limb, axial muscles, or both, } \\
\text { ii. may also have lesser involvement of oropharyngeal } \\
\text { muscles. }\end{array}$ \\
\hline Class IIIb & $\begin{array}{l}\text { MG is characterized by the following: } \\
\text { i. predominantly affecting oropharyngeal, respiratory } \\
\text { muscles, or both, } \\
\text { ii. may also have lesser or equal involvement of limb, axial } \\
\text { muscles, or both. }\end{array}$ \\
\hline Class IV & $\begin{array}{l}\text { MG is characterized by the following: } \\
\text { i. severe weakness affecting muscles other than ocular } \\
\text { muscles, } \\
\text { ii. may also have ocular muscle weakness of any severity. }\end{array}$ \\
\hline Class IVa & $\begin{array}{l}\text { MG is characterized by the following: } \\
\text { i. predominantly affecting limb, axial muscles, or both, } \\
\text { ii. may also have lesser involvement of oropharyngeal } \\
\text { muscles. }\end{array}$ \\
\hline Class IVb & $\begin{array}{l}\text { MG is characterized by the following: } \\
\text { i. predominantly affecting oropharyngeal, respiratory } \\
\text { muscles or both, } \\
\text { ii. may also have lesser or equal involvement of limb, axial } \\
\text { muscles, or both. }\end{array}$ \\
\hline Class V & $\begin{array}{l}\text { MG is characterized by the following: } \\
\text { i. intubation with or without mechanical ventilation, } \\
\text { except when employed during routine postoperative } \\
\text { management, } \\
\text { ii. the use of feeding tube without intubation places the } \\
\text { patient in class IVb. }\end{array}$ \\
\hline \multicolumn{2}{|c|}{ *MG: Myasthenia Gravis } \\
\hline
\end{tabular}

Previous studies have indicated clinical predictions for MG prognosis. Age, gender, thymus anomaly, autoimmune diseases, and initial symptoms of the disease were selected as potential clinical markers for MG prognosis. ${ }^{[17]}$ When MG is diagnosed, treatment usually begins with cholinesterase inhibitors, but most patients will need immune-focused therapy.

In this study, the demographic, clinical, radiological characteristics, prognostic factors, and treatment approaches of MG patients were evaluated. 


\section{MATERIAL AND METHOD}

The study was carried out with the permission of Health Sciences University Dışkapı Yıldırım Beyazıt Training and Research Hospital Clinical Research Ethics Committee (Date: 25.01.2021, Decision no: 103-05). All procedures were performed adhered to the ethical rules and the Helsinki Declaration of Principles.

In 2014-2019, the demographic characteristics, first application complaint, and clinical course, antibody status, electrophysiological and radiological (thoracic tomography) characteristics, and main treatment data of one hundred thirty-eight MG patients who were followed up in the Neuromuscular and Muscular Diseases Polyclinic of our hospital were retrospectively analyzed.

As diagnostic criteria; It was taken into consideration that in EMG; the decrement response exceeding 10\% in repetitive stimulation or the presence of electrophysiological abnormality in the form of prolonged jitter in single-fiber EMG, clinical response to anticholinergic drugs, showing positivity of Ach receptor antibodies in serological tests. ${ }^{[18,19]}$

The demographic characteristics of the patients and first application complaints were evaluated. The patients' neurological examinations, the results of hemogram, routine biochemistry, hormone, and AchRAb laboratory tests were examined. The treatments of the patients who were diagnosed with electrophysiological (ASUT and SFEMG if necessary) examinations were recorded. Records of the patients who were followed up with neurological examinations at regular intervals at the control visits were obtained. These crosssectional data obtained from MG patients were compared with the literature.

\section{Statistical Analysis}

Statistical analyzes were performed by transferring the data to the SPSS ${ }^{\circledR}$ (Statistical Package for Social Sciences) 22.0 program. While evaluating the study data, frequency distributions for categorical variables and descriptive statistics (Mean \pm SD) for continuous variables were given. Independent Sample T-test was used to determine whether there was a difference between two independent groups for normally distributed variables, and Mann Whitney $U$ test was used for variables that were not normally distributed. Chi-square analysis was used to examine the relationship between two independent categorical variables. N (\%) values were given for categorical variables, mean (standard deviation) for normally distributed variables, and median (minimum-maximum) values for nonnormally distributed variables. A p-value of less than 0.05 was considered significant.

\section{RESULTS}

Eighty-three female patients with a mean age of $49.6 \pm 16.13$ and fifty-five male patients with a mean age of $60 \pm 15.63$ were included in the study. The mean duration of disease was $4.8 \pm 5.05$ years.
The first application complaint and initial symptom of the patients were ptosis in $79 \%(n=109) .16$ of them had diplopia as the initial complaint and accompanied by ptoses, dysphagia, and weakness. However, in only 1 of them, the first application complaint was just diplopia. Dysphagia and/ or difficulty swallowing in $7.2 \%(n=10)$ of the patients, limb weakness in $8 \%(n=11)$, weakness in the form of weakness of the neck muscles, and drop head in $5.8 \%(n=8)$ were found as the first application complaint.

According to the Myasthenia Gravis American Clinical Classification Foundation, $79.7 \%(n=110)$ of them were ocular and $20.3 \%(n=28)$ were generalized MG in the first application. During their follow-up, 26 patients continued their follow-ups as generalized MG in $38.4 \%(n=53)$ of all patients in an average of $12.6 \pm 6.81$ (2-28 months) months. At the first diagnosis, stage they diagnosed with; $78.3 \%(n=108)$ were AchRAb positivity, 31.9\% ( $n=44)$ with decrement response in ASUT, and $35.5 \%(n=49)$ with SFEMG findings.

Thymus pathology was found in the thoracic tomography of $37.7 \%(n=52)$ of the patients. $33.3 \%(n=46)$ of the patients had thymectomy. The pathology results of them were thymoma in $8 \%(n=11)$, thymus hyperplasia, or thymic residue in $26.1 \%(n=36)$. One of the patients with thymoma received radiotherapy in addition to thymectomy because of parenchymal invasion.

$38.4 \%(n=53)$ of the patients had the additional autoimmune systemic disease. The most common of these were diabetes mellitus, thyroid diseases, rheumatoid arthritis (RA), Sjögren Syndrome. The clinical course of those with additional autoimmune diseases worsened more often and required additional treatment (intravenous immune globulin). With the initiation of methotrexate in patients with RA, significant clinical benefit was achieved like the literature. ${ }^{[20]}$ After the diagnosis of MG, 4 (2.8\%) patients who experienced pregnancy were closely followed up by adjusting their medications. One of the patients was pregnant twice during MG disease. The patient, who was followed up closely in her first pregnancy, was delivered by a healthy cesarean section. In her second pregnancy, she stopped MG medication herself and did not come to follow up. Her pregnancy resulted in abortion due to fetal growth restriction and fetal death in the gynecological follow-up. Later, he continued his follow-up in our polyclinic.

\section{DISCUSSION}

MG is a relatively rare disease. The incidence of MG has been reported between 9-30 in 1 million (5). When the patients in this study were examined within the years included, 7.2\% $(n=10)-17.3 \%(n=24)$ of the patients were those who were newly diagnosed annually. The patients included in this study were those who were followed up in the Neuromuscular and Muscular Diseases Polyclinic of the hospital, and it was noticed that the number of newly diagnosed patients increased every year compared to the previous years. The reason for this is that the Neuromuscular and Muscular Diseases Polyclinic of our hospital is considered to be the reference center. 
In recent studies, it has been stated that MG is more common especially in the elderly $(1,3)$, the average age of our patients was $53.8 \pm 16.67$ (19-89), $57.2 \%$ of them were over 50 years old. In accordance with the literature, $51.9 \%$ of the patients diagnosed with MG after the age of 50 were male. Female patients were statistically significantly younger $(49.6 \pm 16.13$ years, $\mathrm{p}=0.000$ ).

In $79 \%$ ( $n=109)$ of our patients, the first application complaint was the most common ptosis. The first symptom that occurs in $15 \%$ of the patients; bulbar weakness is known to occur with difficulty speaking, chewing, or swallowing, and can sometimes occur without obvious ocular signs or symptoms in older adults. ${ }^{[1]}$ Bulbar onset was present in 20 (14.4\%) patients in our patients included in study. Although rare, the first complaints in MG can occur with focal weakness in single muscle groups. Defined as "dropped head syndrome", which is rare in the literature, it mainly arises as a result of the weakness of the extensor group neck muscles. ${ }^{[21,22]} 5.8 \%(n=8)$ of our patients presented with complaints of severe head incontinence. As in the patients included in the study, the complaints increase with fatigue, there is usually accompanying ptosis, chewing, and swallowing difficulties.

Autonomic findings such as urinary-fecal incontinence and erectile dysfunction, which are very rare in $\mathrm{MG}$, requiring the exclusion of other causes in case of existence, were present in $3.6 \%(n=5)$ of our patients. Additional examinations and investigations were also performed for patients with these complaints to exclude other causes, and it was concluded that MG had autonomic findings. These complaints completely resolved within 3 months to 1 year in follow-up. It was stated by the patients that especially urinary and fecal incontinence differed during the day, and some days seemed to be completely recovered.

During the 4.5-year follow-up period, 5 patients were followed in intensive care units due to the need for a mechanical respirator. 3 of them recovered and became extubated, and their follow-up continues. Two of the patients died due to pneumonia, respiratory failure, and developing autonomic findings. The etiological cause of the MG crisis and respiratory failure of the patients who died was thought to be an infection.

According to the Myasthenia Gravis American Clinical Classification Foundation, while $79.7 \%(n=110)$ of them were ocular MG patients at the first application, 26 of them were followed up as generalized MG within an average of $12.6 \pm 6.81$ months (2-28 months) months. MG is one of the first diagnoses that come to mind in every patient presenting with ptosis. The physiopathology of the conditions related to the involvement of the autonomic system in MG and the different responses of the drugs used in the treatment have not been fully elucidated yet. Therefore, prospective, larger controlled studies are needed. Treatment decisions and patient follow-up frequency should be individualized according to the severity of MG and coexisting disease, and patient participation in these decisions is crucial for successful management. Few patients can have complete remission in MG. Most patients do not have complete pharmacological remission. Prospective, controlled studies comparing treatments in MG patients are few. With current knowledge and treatments, care must be taken to find the most suitable treatment for each patient. In our study, $33.3 \%$ of the patients had thymectomy. One of the patients with thymoma received radiotherapy in addition to thymectomy because of parenchymal invasion. When MG is diagnosed, treatment is usually started with cholinesterase inhibitors. However, in most patients, it may be necessary to add immune-focused therapy. Physical therapy and rehabilitation, either outpatient or inpatient, are also part of the treatment and are very effective. Another treatment method is surgery. Treatment of maximal thymectomy with sternotomy or minimally invasive approaches can be applied.

The limitation of our study is that we could not determine the pathogenicity of existing and newly identified antibodies in seronegative MG patients. The reason for this was that the testing of antibodies was paid and the patients did not want it.

Over time, specific diagnostic procedures and expert followup improve treatment outcomes. This is particularly important because MG is a potentially reversible disease with treatment options that can make a huge difference to the patient. With the close follow-up and appropriate treatment, the majority of MG patients are able to perform daily living activities and maintain a normal quality of life.

\section{CONCLUSION}

In the diagnosis, follow-up, and treatment process of MG patients; evaluation of the patient by the same clinician team, taking into account other diseases of the patient, individual immunological treatment, and follow-up at a certain frequency constitute the most important parts.

\section{ETHICAL DECLARATIONS}

Ethics Committee Approval: The study was carried out with the permission of Health Sciences University Dışkapı Yıldırım Beyazıt Training and Research Hospital Clinical Research Ethics Committee (Date: 25.01.2021, Decision no: 103-05).

Informed Consent: Because the study was designed retrospectively, no written informed consent form was obtained from patients.

Referee Evaluation Process: Externally peer-reviewed.

Conflict of Interest Statement: The authors have no conflicts of interest to declare.

Financial Disclosure: The authors declared that this study has received no financial support.

Author Contributions: All of the authors declare that they have all participated in the design, execution, and analysis of the paper, and that they have approved the final version. 


\section{REFERENCES}

1. Matthew N. Meriggioli. Myasthenia Gravis: Immunopathogenesis, Diagnosis, And Management. Contınuum (Myasthenic Disorders and ALS) 2009;15(1):35-62.

2. Phillips LH. The epidemiology of myasthenia gravis. Ann N Y Acad Sci 2003;998:407-12.

3. Pakzad Z, Aziz T, Oger J. Increasing incidence of myasthenia gravis among elderly in British Columbia, Canada. Neurology. 2011;76(17):1526-8.

4. Binks $S$, Vincent $A$, Palace J. Myasthenia gravis: a clinical-immunological update. J Neurol 2016;263(4):826j834.

5. Carr AS, Cardwell CR, McCarron PO, McConville J. A systematic review of population based epidemiological studies in Myasthenia Gravis. BMC Neurol 2010;10:46.

6. Renton $\mathrm{AE}$, Pliner $\mathrm{HA}$, Provenzano $\mathrm{C}$, et al. A genome-wide association study of myasthenia gravis. JAMA Neurol 2015;72(4):396Y404.

7. Drachman DB, Adams RN, Stanley EF, Pestronk A. Mechanisms of acetylcholine receptor loss in myasthenia gravis. J Neurol Neurosurg Psychiatry 1980;43(7):601-610.

8. Nicolle MW. Myasthenia gravis. Neurologist 2002;8(1):2-21.

9. Koneczny I, Cossins J, Vincent A. The role of muscle-specific tyrosine kinase (MuSK) and mystery of MuSK myasthenia gravis. J Anat 2014;224(1):29-35.

10. Berrih-Aknin S. Cortactin: a new target in autoimmune myositis and Myasthenia Gravis. Autoimmun Rev 2014;13(10):1001-2.

11. Berrih-Aknin S, Le Panse R. Myasthenia gravis: a comprehensive review of immune dysregulation and etiological mechanisms. J Autoimmun 2014;52:90-100.

12. Binks S, Vincent A, Palace J. Myasthenia gravis: a clinical-immunological update. J Neurol 2016;263(4):826-34.

13. Hohlfeld R, Wekerle $\mathrm{H}$. The thymus in myasthenia gravis. Neurol Clin 1994;12(2):331-42.

14. Nacu A, Andersen JB, Lisnic V, Owe JF, Gilhus NE. Complicating autoimmune diseases in myasthenia gravis: a review. Autoimmunity 2015;48(6):362-8.

15. Gilhus NE, Nacu A, Andersen JB, Owe JF. Myasthenia gravis and risks for comorbidity. Eur J Neurol 2015;22(1):17-23.

16. Jaretski A 3rd, Barohn RJ, Ernstoff RM, et al. Myasthenia gravis: recommendations for clinical research standards. Task force of the Medical Scientific Advisory Board of the Myasthenia Gravis Foundation of America. Neurology 2000;55(1):16-23.

17. Wang L, Zhang Y, He M. Clinical predictors for the prognosis of myasthenia gravis. BMC Neurol 2017;17(1):77

18. Maarika Liik M, Punga AR. Repetitive Nerve Stimulation Often Fails to Detect Abnormal Decrement in Acute Severe Generalized Myasthenia Gravis. Clin Neurophysiol 2016;127(11):3480-4.

19. Baysal Al, Kuruoğlu HR, Odabaşı Z. Olgu Çalışmalarıyla Klinik Elektromyografi Illkeleri, Ankara: Güneş Tıp Kitabevleri, 2012.

20. Karaahmet OZ, Bal A, Dulgeroglu D, Bahceci HK, Cakcı A. Methotrexate treatment in myasthenia gravis. J Clin Neuromuscul Dis. 2014;16(2):106-7.

21. Sawa N, Kataoka H, Eura N, Ueno S. Dropped head with positive intravenous edrophonium, progressing to myasthenia gravis. BMJ Case Rep. 2013;2013:bcr2012007616.

22. D'Amelio M, Di Benedetto N, Ragonese $P$, et al. Dropped head as an unusual presenting sign of myasthenia gravis. Neurol Sci. 2007;28(2):1046. 